\title{
How to establish increased protein intake in a blended lifestyle intervention in community-dwelling older adults?
}

subgroup-analysis of the VITAMIN RCT

\author{
Author(s) \\ van den Helder, Jantine; Verlaan, Sjors; Tieland, Michael; Mehra, Sumit; Visser, Bart; Kröse, \\ Ben J.A.; Engelbert, Raoul H.H.; Weijs, Peter J.M.
}

\section{Publication date}

2020

\section{Document Version}

Final published version

\section{License}

Unspecified

Link to publication

\section{Citation for published version (APA):}

van den Helder, J., Verlaan, S., Tieland, M., Mehra, S., Visser, B., Kröse, B. J. A., Engelbert, R. H. H., \& Weijs, P. J. M. (2020). How to establish increased protein intake in a blended lifestyle intervention in community-dwelling older adults? subgroup-analysis of the VITAMIN $R C T$. Poster session presented at 42th ESPEN congress.

If you believe that digital publication of certain material infringes any of your rights or (privacy) interests,

please let the Library know, stating your reasons. In case of a legitimate complaint, the Library will make the material inaccessible and/or remove it from the website. Please contact the library:

https://www.amsterdamuas.com/library/contact/questions, or send a letter to: University Library (Library of the University of Amsterdam and Amsterdam University of Applied Sciences), Secretariat, Singel 425, 1012 WP Amsterdam, The Netherlands. You will be contacted as soon as possible. 
How to establish increased protein intake in a blended lifestyle intervention in community-dwelling older adults? Subgroup-analysis of the VITAMIN RCT

Jantine van den Helder 1,2, Sjors Verlaan3,4, Michael Tieland11, Sumit Mehra ${ }^{5}$, Bart Visser'1, Ben J.A. Kröse ${ }^{5}$, Raoul H.H. Engelbert1,6, Peter J.M. Weijs 1,7

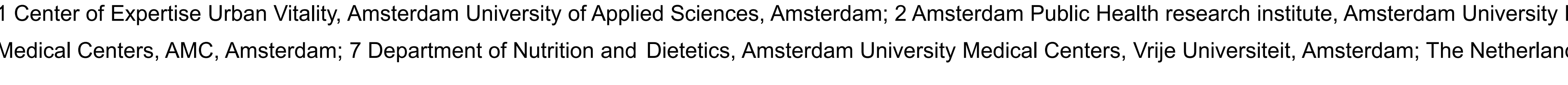

Rationale

In order to prevent sarcopenia in community-dwelling older adults a higher daily protein intake is needed. The dietary protein increasing the protein intake in community-dwelling older adults up to $1.41 \mathrm{~g} / \mathrm{kg} / \mathrm{day}$ after 6 -months intervention and sustaining this intake up to $1.24 \mathrm{~g} / \mathrm{kg} /$ day at 12 -months. In this sub-analysis we determine how the increased protein intake was established.
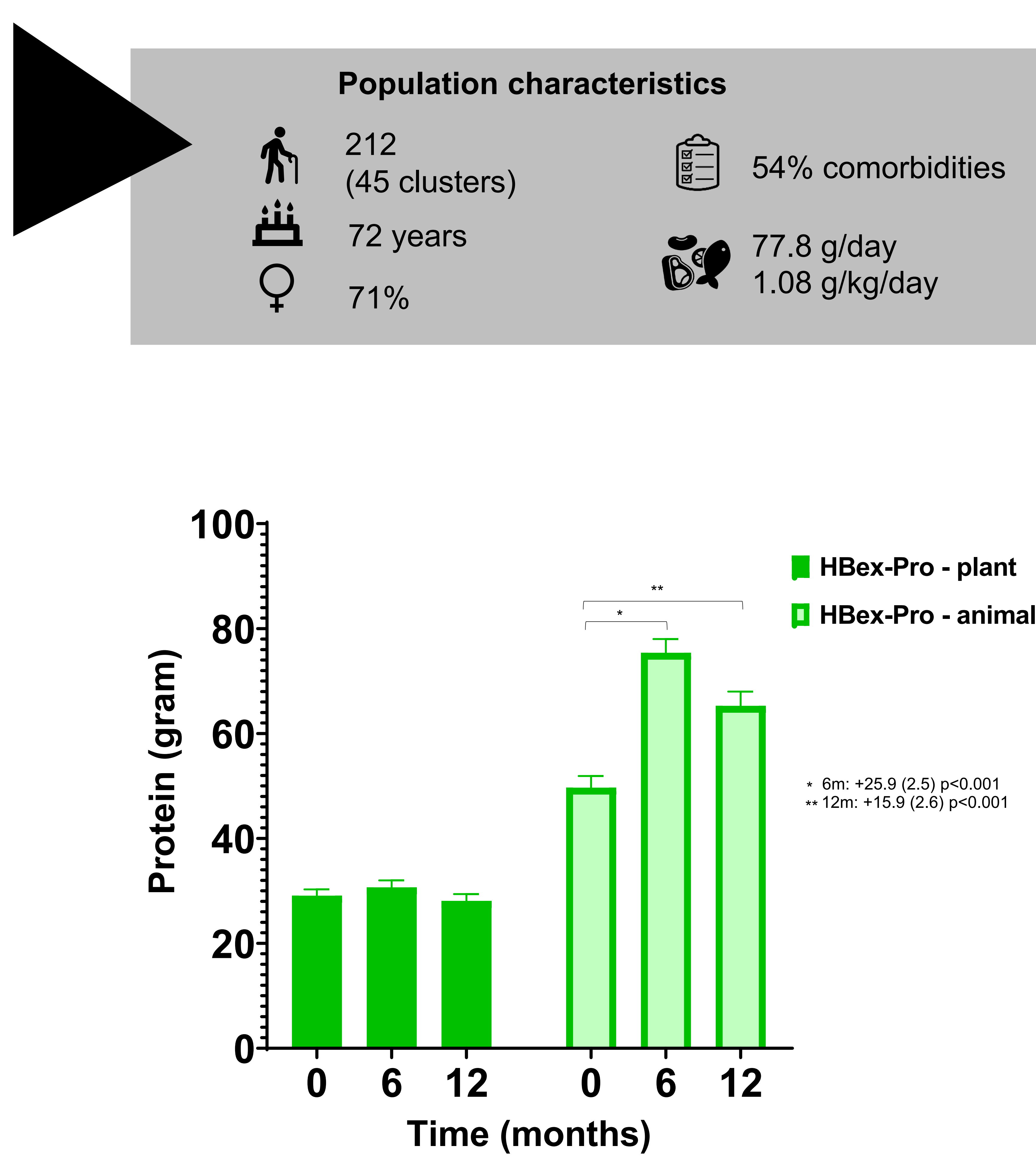

Figure 1. Protein sources in HBex-Pro
Methods

Cluster RCT

-

3 groups: Control / Home-based Exercise / Home-based Exercise + Protein

- Protein sources - Product groups - Amino acids - Intake per meal moment Linear Mixed Models with STATA v13; time and time*group interaction were

Results

Animal protein $(\mathrm{g})$ accounted as major source $(6 \mathrm{~m}+25.9(2.5) \mathrm{p}<0.001$ | $12 \mathrm{~m}$ $+15.9(26) p<0.001)$ (Figure 1) with the main ince +25 in diry products $(\mathrm{g})(6 \mathrm{~m}$ +14.0 (1.4) $p<0.001 \mid 12 \mathrm{~m}+9.76(1.4) p<0.001$ ), followed by fish and meat (Figure 2). This resulted in significant changes in amino acid intake: e.g. leucine (g) $6 m+2.3(0.2) p<0.001 \mid 12 m+1.1(0.2) p<0.001$. Significant increased intake for the protein group was seen at all 6 meal momelts, and particularly at +7.1 (1.2) $p<0.001 \mid 12 \mathrm{~m}+4.0(1.2) \mathrm{p}=0.001$ (Figure 3 ).

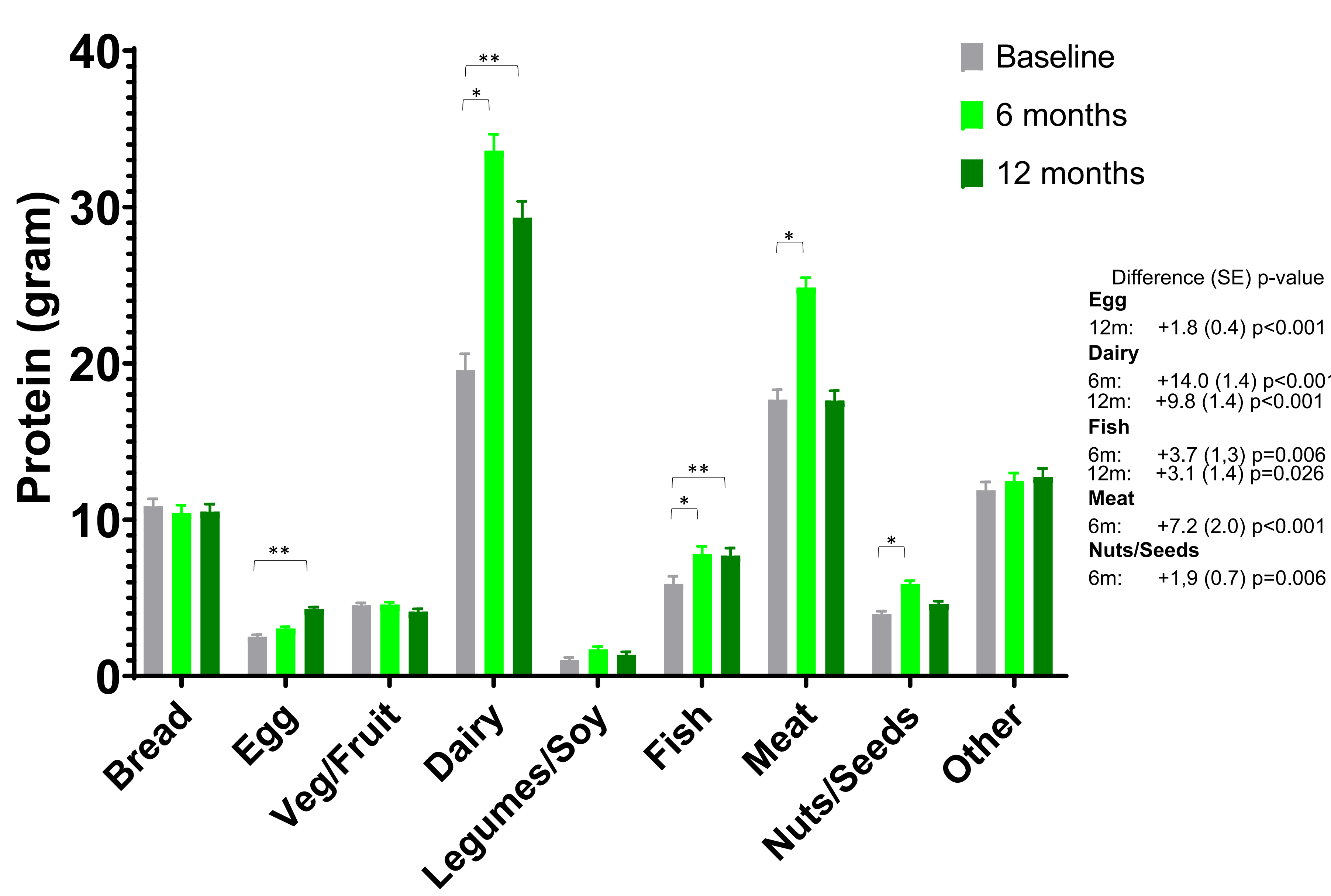

Product groups at time points

Figure 2. Product groups in HBex-Pro

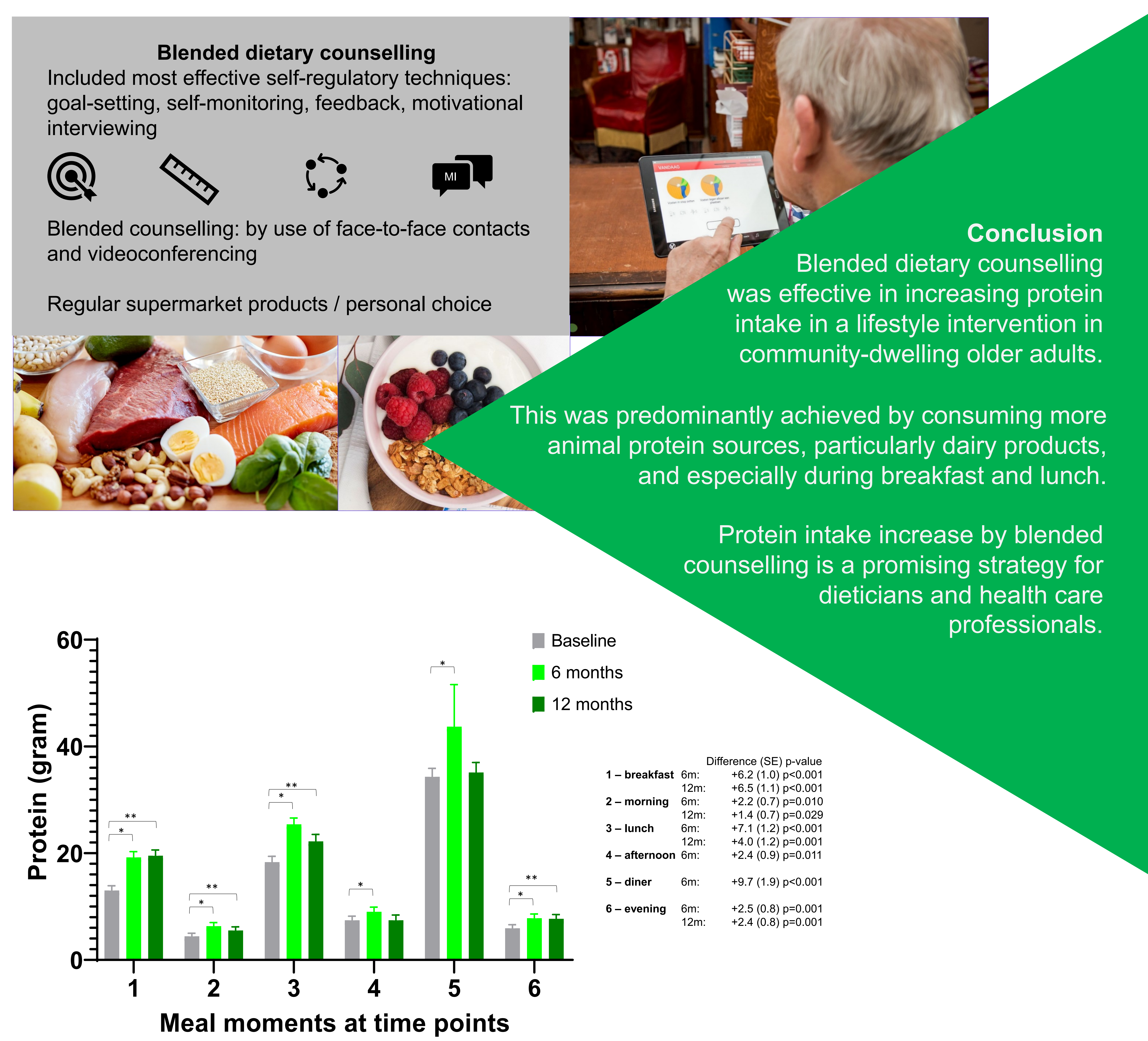

Figure 3. Protein intake during meal moments in HBex-Pro 